\title{
Complicity to Hegemonic Masculinity in D.H. Lawrence's Sons and Lovers
}

\author{
Angelina Subrayan (Corresponding author) \\ Faculty of Modern Languages and Communication \\ Universiti Putra Malaysia \\ Wan Roselezam Wan Yahya \\ Faculty of Modern Languages and Communication, \\ Universiti Putra Malaysia
}

Received: 06-01-2016

doi:10.7575/aiac.ijclts.v.4n.2p.33
Accepted: 09-02-2016

Published: 01-04-2016

\begin{abstract}
Men have long been associated with dominance, strength and confidence and the issue regarding being compliant to the acceptable masculine ideal has always been part of a culture's social identity. This study focuses on the critical discussion on masculinity studies in the classic fiction of D.H Lawrence. Drawing on narrative data from his novel Sons and Lovers (1913), the study examines how hegemonic masculinity is conformed by the male protagonist, Walter Morel, in his gendered relationship. More specifically, the analysis focuses on how the male character aligns himself with the hegemonically authoritarian philosophy of 'tough' masculinity. The effects of social practices and sociohistorical context in which Lawrence wrote these novels are also examined. The study utilises Connell's theory of hegemonic masculinity to explicate Lawrence's depiction of dominant masculinity through his character. The findings reveal that Lawrence aligns his male protagonist to the dominant role by sanctioning aggressiveness, autonomy and violence.
\end{abstract}

Keywords: Hegemonic Masculinity, Dominant Masculinity, Patriarchy, Gender, Power

\section{Introduction}

Connell, in his concept that is related to power relations asserts that men are primarily responsible for the constructions of hierarchical gender relations (Connell, 1995). Insufficient information is identified with regard to the development of hierarchy that takes place but since gender hierarchy functions not only between genders but also within, the emphasis on masculinities is fundamental. The hierarchical gender relations expedite the general subordination of women in gendered relationships. Indeed, while much of the research within the field of gender history is often perceived to be woman-centred, lately the focus of masculinity has begun to be addressed as a topic in its own right (Green and Troup, 1999). Masculinity, according to literary critic Judith Kegan Gardiner is the act of ruling the rapport between men and men in addition to between men and women in society, where in general women are subordinated to men (Gardiner, 2002). Although there are several types of masculinities or various ways of being a man, there is one outstanding type of masculinity that is perceived as the dominant and the most respected form of masculinity among men in certain societies (Kimmel, 2006). In the North American society, what is typically referred to as "hegemonic masculinity" is the principal type of masculinity or the cultural ideal of manliness which is chiefly reflective of white heterosexual who are widely middle-class males (Kimmel, 2006).

In Gender and Power, Connell leads to the sphere of studies that give information on imbalanced relationships in relation to masculinities and femininities as a "state of play" and in this way theorises the leading concept of "hegemonic masculinity" (Connell, 1987:10). In fact, hegemonic masculinity is a complicated concept that is more complex than "patriarchy" where the "social ascendency" is accomplished not simply through violence and assimilation of power, but more significantly in the course of skills linked to powers that range from "religious doctrine" to "mass media". This process fundamentally provides the structure of the overall domination of men to women (Connell, 1987: 184). Most men follow the standard masculine attitude and behaviour of masculine identity which is exposed in the constructing of patriarchal society which the hegemonic masculinity sanctions (Connell \& Messerschmidt, 2005: 7980).

In his book Masculinities, Connell analysed the production of knowledge by considering the domain of masculinity. Connell looked into several major efforts that shaped the science of masculinity in the $21^{\text {st }}$ century. They are the psychoanalysis, the social psychology, gender role theory, sociology, anthropology and history. Connell acknowledges that there are other forms of knowledge on masculinities which are neither clinical nor academic but which are in the form of political knowledge. In chapter two of his book Masculinities, Connell states that the term masculinity is without exception, defined opposite to the term femininity. Reading Lawrence's work "as an interdisciplinary thinker who works readily across and between different cultural forms" is essential in understanding his philosophy and interpreting his literary works. When it comes to Lawrence, whatever he upholds in his idealistic writings are drawn to 
attention in his fiction and, "each was undertaken within the context of the other" (Williams, 1995). As such, understanding Lawrence's characters in relation to hegemonic masculinity may provide knowledge on the standard social practices during the period of industrialisation during the early twentieth century.

The study aims to examine the features connected to hegemonic masculinity in Lawrence's novel Sons and Lovers. Patriarchy and masculinity in this study is understood in the context of hegemonic masculinity that embodies the theory applied by Connell. As such, this study utilises Connell's concept of hegemonic masculinity to explicate significant features related to patriarchy in the character of Morel from Lawrence's novel, Sons and Lovers (1913). These features are analysed based on Lawrence's male protagonist Morel's representation of masculinity. The investigation is focused on the gendered relationship between Morel and his wife, Mrs. Morel. The couple's interactive codes and Lawrence narration are used as the data for analysis. The study utilises the hegemonic theory illustrated by Connell (1995) to elucidate the masculine identity in the novel.

\section{Lawrence's Representation of Marriage}

The fundamental aim of patriarchy in Lawrence's work is to ensure women accept their rightful place in society with regards to their men. The plot of the novel implies Lawrence's intrinsic message that the true success of womanhood is marriage. Lawrence considers marriage to be the only true approach to bring men and women into unity and completeness. Nevertheless, this completeness comes with a powered relationship. The marriage depicted by Lawrence in his novel Sons and Lover (1913), supports his interpretation that individuals are able to attain wholeness through marriage as long as women develop to be submissive wives and men become the authoritarian gender, who impose their dominance on their wives. It seems clear that Lawrence is deliberately rendering a number of discouraging examples of marriages in his novels. Explicitly he says nothing, but one can infer that before presenting the ideal marriage in his mind, Lawrence provides examples in which the roles for men are predominantly in crisis although they embody power.

The notion of hegemonic masculinity is evident in the character of Walter Morel (Morel) as a prelude to viewing masculinity in a historical context and within the domain of class. Morel, one of the male protagonists, whose role is a husband and a father in the novel Sons and Lovers, is from a lower-class mining family. He speaks the local dialect compared to his wife Gertrude Morel's (Mrs. Morel) refined English. His wife, a firm Congregationalist dislikes Morel's habit of consuming alcohol and enjoying dance practices as she considers these activities to be sinful. Morel's failure to be a respectable husband, father, and family breadwinner can be seen in two ways. He can be perceived as a man shattered by the heartless, inhuman industrial system and a man influenced by the exceeding demand of his wife. In addition, Morel can also be seen as his own worst enemy, encouraging self-destruction due to overdose of alcohol and being irresponsible.

Sons and Lovers is a suitable example of an autobiographical novel as a plot with a purpose. Lawrence shaped the male protagonist Morel to foster the dominant male images of patriarchy and aggressiveness. When rationalising the act of dominant masculinity, it is important to remember that men who do not execute their masculinity in a culturally sanctioned approach, are then prone to be shunned or even chastised by the society. Sons and Lovers being an autobiographical novel is concerned with its social and historical background and naturally shows a strong involvement in the narrative in its socio-historical context.

\section{Socio-historical Context of Sons and Lovers}

In the society of Bestwood, the English coal-mining town in Nottinghamshire where the novel is predominantly set, men were previously assigned in the combat role where toughness, endurance, courage and emotional restraint were required from them. Women had to handle both the household responsibilities and also for many, the agony of the battle zone. They arrived into the industrial world in the nonexistence of men due to war, only to be displaced back to the kitchen when the war ended. Men came back from fighting the war and the next stage required them to search for jobs. Sadly, only later it was known that these men were traumatised by their war experiences, but this was preceding the beginning of counselling. It is not shocking that consequently, many faced immense problems in adapting to civilian life. Although Morel did not join the army to combat the war, the effect of the war in the industrial society shaped his hegemonic masculine behaviour. Masculine principles are often controlled or overpowered by society, and only by applying and demonstrating that primitive male soul, can masculinity be re-established and sanctioned. This is what Morel, the dominant male character was trying to achieve.

\section{Hagemonic Masculinity in Sons and Lovers}

Patriarchy is a central feature in Morel in the first part of Sons and Lovers. Morel is an English collier and in numerous ways representative of the literary image of the lower-class working man. Masculinity is enacted in a different way by Morel in different scenes. In the first part of the novel, the young Morel demonstrates his male authority towards his wife and children. Morel is not the type of man who is interested in skills, in matters dealing with the intellect, or even in his work. For him his work is simply a source of income. He is a man who survives for whatever gratifications he can find in eating, drinking, and sleeping. In the beginning of his life, Lawrence portrayed Morel as a warm-hearted vibrant man but after his marriage he becomes rough and violent to his family and frequently attacks them verbally and physically. Mrs. Morel, his wife represents little to him due of her puritanical thoughts and respect for her culture. Owing to his authoritative nature, the first glow of the couple's marriage diminishes and he eventually becomes isolated from his children. Mrs. Morel is depicted by the conflict of duality. This duality is seen in the division of her role as a wife and her responsibilities toward her children. Lawrence's own mother, like the female character Mrs. Morel, was of 
middle-class reputable family, and had come down in the world since the 1839 decline in the lace-trade. Along these and other borders, Lawrence's life is shaped and fastened, and it is through these boundaries that Lawrence was mindful of the emerging drawback of classism. Classism is one of the main reasons for the Morels constraints in their marriage.

In chapter one of the novel, we discover through Lawrence's narration, the first meeting between the couple. At the onset of the novel, Lawrence provides rather an intensely masculine optimistic account of Morel as he is described as "well set-up, erect, and very smart" (9) with "black wavy hair and a thick beard" (9). Besides, readers are also given insight into his character, where Morel laughed a great deal during the first meeting, hence signifying a happy and peaceful figure. Mrs. Morel was charmed by Morel's self-determination and aesthetic life. This is the first ideal physical description of Morel as a stereotype masculine man. He is portrayed as practicing the conventional masculine character since he is depicted as a robust person and posses almost all the quality of a male macho character. The reason for the couple's initial attraction towards each other is due to the fact that Morel and his lifestyle embodied everything that is contrasting to what Mrs. Morel had experienced before, with her own father. Mrs. Morel's fascination to Morel was basically grounded on the desirability that could occur between the opposites. Morel was an attractive man, and he also seems a relatively bold and likable character and it is not surprising that Mrs. Morel discovers herself extraordinarily drawn to Morel, despite being portrayed as "opposite" to her new found love. When Mrs. Morel first encounters Morel, she loves him since she believes he is truly manly. Since he is a miner who devotes all his time underground breaking rocks it is reasonable that she would find this to be a masculine feature that implies a strong and stout character. Nevertheless, like countless women who fall in love with "manly" youthful men, Mrs. Morel finally discovers that there is a dark side to this type of masculinity. Her husband turns out to be an abusive alcoholic. Besides, she also found out that he is not concern about sharing his feelings, or apologising for whatever mistakes he does. As a man he is not suppose to show his emotion as this will damage his masculine identity.

One of the characteristics of a patriarchal figure is being the breadwinner of the family. The continuous and most significant descriptions in the lifetime of the Morels is the financial or economical feature that molded their interactions with each other. It is imperative to discuss here that Morel had described his financial incomes as being rosier than they really were to his wife during their courting period. It is important to look into the financial constrains and complications that stained the conflicts and struggles between the couple. Many critics focused on the psychological aspect of the relationships between the Morels thus depriving the connection between the psychological and economical issues that are evidently apparent in the novel. The relationship between the husband and wife was predominantly based on the economical level and it was ruined when Morel was futile in accomplishing his responsibility as the breadwinner of the family.

The rapport between Mrs. Morel and her husband was mostly centered on the economical level and it was shattered when Morel was unsuccessful in accomplishing his duty as the breadwinner of the family. Since the Morels' marriage has been established exclusive without any foundations on equality, social status and education, there is certainly nothing stable in it. The only link between the couple is their children. Therefore, his wife turns to them and avoids her husband. Inferior socioeconomic prestige men want submissive, dutiful, and hardworking wives. Morel shows his dominant character by expecting all these responsibilities from his wife but he chooses not to deliver his obligations.

Mrs. Morel and her husband arose to characterise two diverse classes in the family and the social structure. Through them, it can also be seen that the disparities between these two classes lie not only in the economical and social plain, but also in the ideological plane. Mrs. Morel has married beneath her class. In the beginning she was apprehensive about the idea of moving to The Bottoms but it was the best she could do to get away from her father's puritanical restrictions and ascertain some kind of individual liberty. The class struggle between Morel and his wife undoubtedly justifies some of the problems between them. It is, nonetheless, questionable to be the only influence dividing them, the one which especially alienates Morel from his family and home. Ironically, Mrs. Morel's subtle portrayal of strength in the initial part of the married life is partly prompted by her subordination in many situations. Simultaneously, these situations repeatedly demonstrate how the "madness" of the masculine power struggle (Kelsey, 1991: 71) also upsets Mrs. Morel: "[She] tends to laugh [...] in the moments when her oppression boldly exposes its nakedness to her" (Kelsey, 1991: 91). This response, hysteria or "bitter irony" (p. 91), functions to indicate the dependency of Mrs. Morel to the dominant Morel. Besides, she is physically and economically powerless alongside her husband.

Classism developed in the English society due to circumstances such as the growing effects of industrialisation and the transition from the rustic to the contemporary style of survival in the constitutions of the English society. Thus, most of the struggles and encounters in the storyline of Sons and Lovers were predominantly constructed on the class biasness and materialistic ideals that comprised the leading factors behind the ignition of these conflicts. The class division and discontentment is explicitly made evident in the relationship between Morel and his wife, Mrs. Morel. In one of the scenes in the novel, Mrs. Morel learns that her husband had been lying to her regarding the payment for their house furniture, and about being the owner of the house which they are staying in and the house next to it. Later in their marriage she also found out that this lie and the dissimilarities in the social and economical status were the key forces resulting in their failed marriage:

And how much has he sunk in his houses?" she asked.

His houses-which houses?

Gertrude Morel went white to the lips. He had told her the house he lived in, and the next one, was his own. (Lawrence 13) 
Morel, knowing that one of the ways to sanction his dominant character, is to own a house. Since he could not afford to buy a house, he lied to his wife to sustain his position as a dominant husband and to proof to the society that he is a man. The lies about the houses exemplifies Morel's attitude as a man living in a male dominant society. Issues relating to owning a house are devoutly the task of a man and it is his responsibility to own a house for his family. Since Morel cannot afford a house, lying was the only solution for him to prove his masculine identity to his wife. However, the lies concerning the unpaid bills and possessing the house caused Mrs. Morel to gradually loathe the man she formerly fell in love with. To be a role model, she supports the idea that a husband has to provide financial establishment as well as exemplify the family domain in the society that magnifies the hegemonic masculinity discourse inside it. When men fail their responsibilities in the social and economic means, their only approach to feel assured of a sense of accomplishment is to uphold their position as head of the household. Patriarchal hierarchy and family organisation emphasise the divisions of lives, as women work inside the home and men work out of their homes. The concept of hegemonic masculinity in Sons and Lovers advocates that gender develops more from social drilling than from biology. Morel is not actually a high-ranking worker down the pits as he once declared, and does not possess neither his home nor all the furniture. Nevertheless, the chaos the couple experience due to these deceptions is not solely Morel's mistake.

Morel projects his authority by paying heed to his family's expectations as a husband and a father. The position of dominant masculinity is seen here when he begins to get physically violent with his wife due to his nature of being intoxicated. His drinking habit and his male aggressive character shaped violence in Morel's dominant personality, when he chased Mrs. Morel out of the house in one of the desperate scenes in the novel:

The house is filthy with you, she cried. Then get out on it - it's mine. Get out on it! he shouted. It's me as brings th' money whoam, not thee. It's my house, not thine. Then ger out on't—ger out on't! (Lawrence 22)

In the above extract Morel conforms to hegemonic masculinity when he pushes his pregnant wife out into the winter night and locks the door against her. The gap between the husband and wife was the main source for this shattered marriage that was portrayed later by violence, detestation and unpleasantness.

There is also a section, perhaps the most significant in chapter one, where Morel cuts his son, William's hair. Morel makes a decisive and powerful decision knowing very well that his wife will not be happy. He does not like his son looking like a petite girl and so one fine day he cuts off all of the boy's hair. Mrs. Morel unquestionably adores each little hair on William's head, so when she discovered what had happened, she became hysterical:

...the child - cropped like a sheep, with such an odd round poll--looking wondering at her; and on a newspaper spread out upon the hearthrug, a myriad of crescent-shaped curls, like the petals of a marigold scattered in the reddening firelight. (Lawrence 15)

This scene specifically supports the fact that Morel tries to create issues which go against his wife's likings by cutting of his son's hair. He portrays his dominant role by deliberately going against his wife's wishes to do as he pleases. There is no effort on Morel's part to resolve the situation between the couple but what is seen here is the act of a man depicting heroism in a negative way while simultaneously depicting his aggressive nature.

Mrs. Morel was mindful that her husband did not match her social class in his behaviour. Morel was a modest miner with no actual aspiration to rise to any new social class but Mrs. Morel hunted him to improve himself financially and socially to be recognised within the privileged bourgeoisie of the English society. When he was unsuccessful in meeting with her great hopes, she deserted him and was emotionally exasperated to accomplish her ambitions through her sons, William and Paul:

The pity was, she was too much his opposite. She couldn' be content with the little he might be; she would have him the much that he ought to be. So, in seeking to make him nobler that he could be, she destroyed him she injured and hurt and scarred herself, but she lost none of her worth. She also had the children." (Lawrence 21).

Mrs. Morel believed that she had the potential to transform and promote him into her social class, but she failed and that eventually wrecked their relationship. Undeniably Morel has an immense role to play, but so does Mrs. Morel, who wholeheartedly hurried into a marriage with a man she hardly knows. She simply took his words for his social class and financial status without any doubts and this is something that is scarcely done in the era of industrialisation. Morel is "despised" by Mrs. Morel, an extremely severe term to use, but one that is reasonable. He was untruthful to her from the beginning, being an alcohol dependent and a somewhat insignificant father and husband. Mrs. Morel's response is seamlessly reasonable that one would deliberate on. To project his masculine self, Morel defends his behaviour and condemns his wife's conducts.

\section{Conclusion}

Morel's unsuccessful relationship shows the fundamental disasters in conventional gender roles. But the tensions for Lawrence, as for Morel, were not only affecting those living in the urban area but also among those living in the country. Within the family, the key elements of class difference and class-perspective caused further shatters and 
tensions in the name of the dominant type of masculinity. The friction due to hegemonic masculinity, created many conflicting constraints between the couple's relationship. Lawrence portrays Morel's depiction of hegemonic masculine identity as both visibly and furtively. In the novel, there are whole passages deliberating on the nature of the Morels' relationship, and more important issues on dominant masculinity that are implicit in symbolic set-pieces. Lawrence's philosophy can also be seen in the organisation of his work as a whole when Mrs. Morel did not get the contentment she desired from her husband, so the children become a medium for her love but however, this impairs the development of the children. The unhealthy desire to practice hegemony is seen here as a result of the capitalist structure that has infected the English society with the longing for materialistic possessiveness. This male supremacy that was instilled in the society by the capitalist propaganda has transformed people into either machines in the hands of the materialism or products stripped out of any individual personalities. Morel displayed his dominant role by authorising antagonism, sovereignty and violence. Men are not born with masculinity as a portion of their hereditary disposition but somehow, it is an idea men are accustomed to due to social practice. Masculinity includes social codes of behaviour, which men are to repeat in culturally suitable ways.

\section{References}

Connell, R. (1995). Masculinities. Berkeley: University of California Press.

Connell, R. (1987). Gender and power: Society, the person, and sexual politics. Stanford, Calif: Stanford University Press.

Connell, R. W. \& Messerschmidt, J.W. (2005). "Hegemonic Masculinity: Rethinking the Concept." Gender and Society, 19(6). pp.829-59.

Green, A., \& Troup, K. (1999). The houses of history: A critical reader in twentieth-century history and theory. Manchester: Manchester University Press.

Gardiner, J. K. (2002). Masculinity studies \& feminist theory: New directions. New York: Columbia University Press.

Kelsey, N. (1991). D.H. Lawrence: Sexual crisis. New York: St. Martin's Press.

Kimmel, M. S. (2006). Manhood in America: A cultural history. New York: Oxford University Press.

Lawrence, D. H. (1995). Sons and Lovers. London: Penguin Books.

Williams, L. R., \& British Council. (1997). D.H. Lawrence. Plymouth, U.K: Northcote House in association with the British Council. 